\title{
Intensive care unit family satisfaction survey
}

\author{
SM Lam *, HM So, SK Fok, SC Li, CP Ng, WK Lui, DK Heyland, WW Yan
}

\section{A B S T R A C T}

Objectives: To examine the level of family satisfaction in a local intensive care unit and its performance in comparison with international standards, and to determine the factors independently associated with higher family satisfaction.

Design: Questionnaire survey.

Setting: A medical-surgical adult intensive care unit in a regional hospital in Hong Kong.

Participants: Adult family members of patients admitted to the intensive care unit for 48 hours or more between 15 June 2012 and 31 January 2014, and who had visited the patient at least once during their stay.

Results: Of the 961 eligible families, 736 questionnaires were returned (response rate, 76.6\%). The mean ( \pm standard deviation) total satisfaction score, and subscores on satisfaction with overall intensive care unit care and with decision-making were $78.1 \pm 14.3,78.0 \pm 16.8$, and $78.6 \pm 13.6$, respectively. When compared with a Canadian multicentre database with respective mean scores of $82.9 \pm 14.8,83.5 \pm 15.4$, and $82.6 \pm 16.0(\mathrm{P}<0.001)$, there was still room for improvement. Independent factors associated with complete satisfaction with overall care were concern for patients and families,
This article was published on 15 Sep 2015 at www.hkmj.org. intensive care unit environment. A performanceimportance plot identified the intensive care unit environment and agitation management as factors that required more urgent attention.

Conclusions: This is the first intensive care unit family satisfaction survey published in Hong Kong. Although comparable with published data from other parts of the world, the results indicate room for improvement when compared with a Canadian multicentre database. Future directions should focus on improving the intensive care unit environment, agitation management, and communication with families.

\section{Hong Kong Med J 2015;21:435-43}

DOI: $10.12809 / \mathrm{hkmj} 144385$

\author{
${ }^{1}$ SM Lam *, MB, BS, FHKAM (Medicine) \\ ${ }^{1} \mathrm{HM}$ So, MN, MSc \\ ${ }^{1}$ SK Fok, MN \\ ${ }^{1} \mathrm{SC}$ Li, RN, MN \\ CP Ng, BSN \\ ${ }^{1}$ WK Lui, RN \\ DK Heyland, MSc, MD \\ WW Yan, MB, BS, FHKAM (Medicine)
}

${ }^{1}$ Department of Intensive Care, Pamela Youde Nethersole Eastern Hospital, Chai Wan, Hong Kong

${ }^{2}$ Department of Medicine, Queen's University, Kingston, Ontario, Canada

* Corresponding author: lamsm2@ha.org.hk

New knowledge added by this study

- This study provides the first dataset on the level of family satisfaction with intensive care unit (ICU) care in Hong Kong.

- Factors that independently affected family satisfaction include the ICU environment, agitation management, and communication between health care workers and families. These are all potentially amenable to improvement.

Implications for clinical practice or policy

- Factors identified to be independently associated with higher family satisfaction will provide directions for future improvement.

- Such baseline data will allow for assessment of the efficacy of future improvement initiatives.

\section{Introduction}

Providing professional care and establishing a good rapport with patients is the mission of all health care workers. This relationship building is part of the patient-centred health care delivery model that is currently being advocated over a clinicianor disease-centred model. ${ }^{1}$ It is associated with better clinical outcomes and may reduce potential complaints due to miscommunication..$^{2-4}$ In the intensive care setting where patients often cannot make their own decisions, either due to their illness or to the effect of medications, ${ }^{5}$ building a good relationship with the patients' family is especially important. Furthermore, it has been recognised that families of patients admitted to the intensive care unit (ICU) are at higher risk of developing anxiety, depression, and post-traumatic stress disorder., They are suddenly subjected to an uncertain outcome 


\section{深切治療部病人家屬滿意度調查 林倩雯、蘇杏梅、霍斯琪、李笑珍、吳靜萍、呂惠琼、 DK Heyland、殷榮華}

目的：探討深切治療部（ICU）患者家屬的滿意度, 與國際標準作比 較, 並找出與較高滿意度相關的獨立因素。

設計：問卷調查。

安排：香港一所分區醫院的內外科成人ICU。

參與者：2012年6月 15 日至2014年1月 31 日期間病人入住ICU不少於 48小時並於逗留期間曾到訪至少一次的家庭成員。

結果：961個符合條件的家屬中, 共收回問卷736份（回應率76.6\%）。 對於ICU整體護理總滿意度評分的平均值（土標準差）為78.1 \pm 14.3 , 其整體護理次量表得分為 $78.0 \pm 16.8$, 另決策次量表得分為 $78.6 \pm$ 13.6 。另一個加拿大多中心研究的評分依次為 $82.9 \pm 14.8$ 、 $83.5 \pm$ 15.4 和 $82.6 \pm 16.0 （ \mathrm{P}<0.001)$ 。比較兩組的數據, 發現本地ICU患 者的家屬滿意度仍有改進的空間。與ICU整體護理完全滿意的獨立相 關因素為對病人和家屬的關心、躁動管理、與護士溝通的次數、醫生 的能力和表現, 以及ICU環境。重要度一表現程度分析法確定ICU環 境和躁動管理兩項因素均須更迫切關注。

結論 : 這是本港首個ICU患者家屬滿意度的調查。雖然結果可媲美世 界其他地區公佈的數據, 但若與另一項加拿大多中心研究的評分比 較, 本研究的結果還有改進的空間。未來發展方向應着重改善ICU環 境和躁動管理，以及與病人家屬的溝通。 for their loved ones, with associated emotional, social and financial consequences, and in a strange environment packed with complex technological advancements. The long-term psychological impact on the family after an ICU encounter is now termed as post-intensive care syndrome-family (PICS-F).? This adds to the society's health care burden and reduces the family ability to provide care. Evidence suggests that the risk of developing PICS-F is affected by the manner in which health care workers interact with the family. ${ }^{8}$ For these reasons, ICU quality measurement should include the families' perspective and their satisfaction with the care process. ${ }^{9,10}$

In early 2012, the Department of Intensive Care, Pamela Youde Nethersole Eastern Hospital, Hong Kong (PYNICU) initiated the Family Satisfaction Enhancement (FAME) programme that aimed to improve family satisfaction with ICU care. A regular satisfaction survey was performed that intended to identify problem areas and make subsequent improvements. The current study was part of the FAME programme that evaluated the level of family satisfaction in a local ICU and its performance in comparison with international standards, and determined factors that are independently associated with a higher family satisfaction and could be used to plan future initiatives.

\section{Methods}

This was a questionnaire survey carried out at PYNICU, which is a mixed medical-surgical 22-bed adult ICU in a regional hospital with 1633 beds in Hong Kong. It is a closed ICU with 24-hour intensivist coverage.

The Family Satisfaction in the ICU (FSICU) questionnaire is a patient family satisfaction questionnaire originally developed in 2003 by a group of health care professionals in Canada: the Canadian Researchers at the End of Life Network (CARENET). ${ }^{5}$ The questionnaire has been validated for use in North America and Europe, ${ }^{11-14}$ and has been translated into other languages including Chinese. The questionnaire is accessible online (http://www.thecarenet.ca). The questionnaire consists of 37 items in two parts: satisfaction with overall ICU care, and satisfaction with decisionmaking around the care of critically ill patients; and three open-ended questions. Respondents were asked to provide baseline data (sex, age, relationship with the patient, prior experience with ICU, and whether they lived together before admission) at the start of the questionnaire. Corresponding patient data were retrieved from the Clinical Management System, electronic Patient Record, and Clinical Data Analysis and Reporting System.

Patients who were admitted to the ICU for 48 hours or more between 15 June 2012 and 31 January 2014, and were visited by their next-of-kin (NOK; defined as the key contact person nominated by the family and documented on the nursing chart on admission) during their stay in the ICU were eligible. Once an eligible patient was nearing ICU discharge (defined as an expected date of ICU discharge within the next 5 days as judged each morning by a senior clinician or nurse consultant), or had passed away in the ICU, his/her NOK was invited by an independent research assistant not involved in clinical care to participate in the survey. A minimum stay of 48 hours was used as in previous studies to ensure an adequate exposure of families to the ICU. ${ }^{15,16}$ A copy of the questionnaire and an envelope were given to the NOK to be completed based on his/her opinion. He/she was asked to return the questionnaire in the envelope provided, which was opened only by researchers. Those who failed to return the questionnaire were contacted by phone within 2 months of ICU discharge or death, and the questionnaire was sent to them with a stamped addressed envelope if they agreed to participate. All respondents were ensured of the confidentiality and anonymity of their response. For patients who were admitted to the ICU more than once within the same hospitalisation, only the last was analysed.

The study protocol was reviewed by the Hong Kong East Cluster Ethics Committee and the need for consent was waived. 


\section{Statistical analyses}

Items in the FS-ICU questionnaire were scored as previously described ${ }^{12}$ : each item was recoded into a linear scale ranging from 0 to 100 , with 0 as very poor or very dissatisfied, and 100 as excellent or completely satisfied. Three items ("received appropriate amount of information", "had enough time to think in decisionmaking process", and "adequate time to address concerns and answer questions") were recoded into dichotomous variables, while two items ("involved at right time in decision-making process", and "given right amount of hope patient would recover") were recoded into a 3-point Likert scale. ${ }^{12} \mathrm{~A}$ mean ( \pm standard deviation [SD]) score was computed for each item. Subscores for satisfaction with overall ICU care (FS-ICU/Care) and satisfaction with role in decision-making (FS-ICU/DM), and a total score (FS-ICU/Total) were generated by averaging available items, provided that the respondent answered $70 \%$ or more of the items in the respective sections. ${ }^{12}$

Results were compared using Mann-Whitney $U$ test with those of a multicentre Canadian database (written communication, Daren Heyland, Feb 2014) that comprised data captured from 2003 to 2006 at 12 Canadian sites.

Univariate analyses of satisfaction with overall ICU care and satisfaction with role in decisionmaking were conducted. Variables included the baseline respondent's and patient's characteristics, as well as items of part 1 or part 2 ofFS-ICU, respectively. Continuous variables were categorised using their median, and questionnaire items were categorised into "completely satisfied" and "less than completely satisfied". Factors with a P value of $\leq 0.1$ were entered into multivariable logistic regression using stepwise backward elimination to identify independent factors associated with complete family satisfaction with overall ICU care and role in decision-making.

The independent factors thus identified by multivariable logistic regression were used in the construction of performance-importance plots to identify those factors that deserve more urgent attention because of their higher importance (regression weights above the median) but lower performance (percentage of that item being rated as "excellent" being below the median).

By applying the rule of 10 on logistic regression analysis of family satisfaction with overall ICU care, a target sample size was estimated to be 725 with 29 covariates with an estimated $40 \%$ of respondents being "completely satisfied" with overall care. All tests were two-sided, and a P value of $<0.05$ was considered statistically significant. All data were analysed using the Statistical Package for the Social Sciences (Windows version 20; SPSS Inc, Chicago [IL], US).

\section{Results}

From 15 June 2012 to 31 January 2014, 961 patients were eligible and 822 families agreed to participate; 736 questionnaires were eventually returned, with a response rate of $76.6 \%$. Excluding the three questions only applicable to families of patients who passed away in ICU and the three openended questions, 23766 (95.0\%) of the total 25024 questions were completed. Baseline characteristics of the respondents and patients are shown in Table 1.

Our mean ( \pm SD) FS-ICU/Total, FS-ICU/Care, and FS-ICU/DM scores were 78.1 $\pm 14.3,78.0 \pm$ 16.8 , and $78.6 \pm 13.6$, respectively. Table 2 shows the percentage of responses and mean score for each questionnaire item.

When results were compared with the Canadian data (written communication, Daren Heyland, Feb 2014), the latter had a higher mean FS-ICU/Total, FS-ICU/Care, and FS-ICU/DM score of $82.9 \pm 14.8$, $83.5 \pm 15.4$, and $82.6 \pm 16.0$, respectively $(\mathrm{P}<0.001$ for all three scores when compared with PYNICU). Table 2 shows the result for each FS-ICU item; PYNICU achieved a significantly higher mean score for item "control over care". There was no significant difference in scores between the two databases for items "frequency of communication by physicians", "atmosphere of ICU waiting room", "involved at the right time in decision-making" "received appropriate amount of information", and "given right amount of hope". The Canadian sites achieved higher scores for the remaining items.

In the univariate analysis of satisfaction with overall ICU care, none of the patient's or respondent's characteristics had a $\mathrm{P} \leq 0.1$. Items "spiritual support for family", "support from social workers", and "support from pastors" were excluded since more than $30 \%$ of the responses were either missing or deemed not applicable. Thus, a total of 14 covariates were analysed in the multivariable analysis. The independent factors identified were "concern and caring for patients", "agitation management", "concern and caring for family", "frequency of communication by nurses", "physician skill and competence", "atmosphere of ICU", and "atmosphere of ICU waiting room" (Table 3). In the multivariable analysis of satisfaction with role in decision-making, 16 covariates including "age of respondent", "sex of respondent" (with $\mathrm{P}$ values of 0.005 and 0.08 , respectively in the univariate analysis), and all items in part two of the questionnaire excluding item "given right amount of hope" $(\mathrm{P}=0.214$ in univariate analysis) were tested. Independent factors identified were "honesty of information", "completeness of information", "control over care", "agreement within family regarding care patient received", "satisfaction with amount of health care", and "age of respondent $\geq 47$ years" (Table 3 ).

Performance-importance plots identified the following items as being more important but performed less satisfactorily: "atmosphere of ICU 
TABLE I. Baseline characteristics of respondents and patients $(n=736)$

\begin{tabular}{|c|c|}
\hline Characteristic & $\begin{array}{l}\text { No. }(\%) \text { or median } \\
\text { (interquartile range) }\end{array}$ \\
\hline \multicolumn{2}{|l|}{ Respondents } \\
\hline \multicolumn{2}{|l|}{ Sex } \\
\hline Female & $421(57.2)$ \\
\hline Male & $315(42.8)$ \\
\hline Age (years) ${ }^{*}$ & $47(38-55)$ \\
\hline \multicolumn{2}{|l|}{ Relationship with patient } \\
\hline Children & $350(47.6)$ \\
\hline Spouse & $164(22.3)$ \\
\hline Parent & $87(11.8)$ \\
\hline Sibling & $81(11.0)$ \\
\hline Others $†$ & $54(7.3)$ \\
\hline \multicolumn{2}{|l|}{ Prior experience with ICU } \\
\hline No & $513(69.7)$ \\
\hline Yes & $218(29.6)$ \\
\hline \multicolumn{2}{|c|}{$\begin{array}{l}\text { Lives with patient before current } \\
\text { admission }\end{array}$} \\
\hline No & $354(48.1)$ \\
\hline Yes & $382(51.9)$ \\
\hline \multicolumn{2}{|l|}{ Patients } \\
\hline \multicolumn{2}{|l|}{ Sex } \\
\hline Female & $290(39.4)$ \\
\hline Male & $446(60.6)$ \\
\hline Age (years) & $68(55-80)$ \\
\hline \multicolumn{2}{|l|}{ Ethnic group } \\
\hline Asian & 728 (98.9) \\
\hline Caucasian & $2(0.3)$ \\
\hline Others & $6(0.8)$ \\
\hline \multicolumn{2}{|l|}{ ICU admission diagnosis } \\
\hline Medical & $502(68.2)$ \\
\hline Postoperative & $234(31.8)$ \\
\hline \multicolumn{2}{|l|}{ No. of co-morbid disease } \\
\hline None & $139(18.9)$ \\
\hline 1 & $186(25.3)$ \\
\hline 2 & $178(24.2)$ \\
\hline 3 & $233(31.7)$ \\
\hline APACHE II score & $23(17-29)$ \\
\hline \multicolumn{2}{|l|}{ Mechanical ventilation } \\
\hline No & $183(24.9)$ \\
\hline Yes & $553(75.1)$ \\
\hline ICU length of stay (days) & $5(3-10)$ \\
\hline \multicolumn{2}{|l|}{ ICU survival } \\
\hline Survived & $672(91.3)$ \\
\hline Died & $64(8.7)$ \\
\hline \multicolumn{2}{|c|}{$\begin{array}{l}\text { Abbreviations: APACHE = Acute Physiology And Chronic Health } \\
\text { Evaluation; ICU = intensive care unit } \\
\text { * Total No. = 7I6 } \\
+ \text { Others included in-laws, grandparent, grandchildren, cousin, } \\
\text { aunt, nephew, and niece } \\
\ddagger \quad \text { Total No. }=731\end{array}$} \\
\hline
\end{tabular}

waiting room", "atmosphere of ICU", "agitation management" (overall care), and "satisfaction with amount of health care" (decision-making) [Fig 1].

\section{Discussion}

This is the first ICU family satisfaction survey published in Hong Kong, and was conducted following implementation of the FAME programme in 2012. Following a small-scale survey carried out by PYNICU in 2010 (written communication, HL Wu, 2012), staff awareness about the importance of family satisfaction has increased. Family satisfaction was added to the regular agenda at our weekly business meetings, where comments and feedback from NOKs were discussed. These discussions led to various measures to improve communication (unsolicited nurses' update during visiting hours), access to information (information booklets in waiting rooms and noticeboard displays for families), and facilities (chairs for families at bedside, televisions for awake patients, and refurbishment of the waiting rooms). This survey showed high satisfaction scores in 2012 to 2014 that were similar to figures reported around the world (Fig $2^{16-18}$ as well as the multicentre Canadian database) - a German study reported their mean FS-ICU/Total, FS-ICU/Care, and FS-ICU/DM as $78.3 \pm 14.3,78.6 \pm 14.3$, and $77.8 \pm 15.6^{16}$; a Swiss study reported scores of $78 \pm 14,79 \pm 14$, and $77 \pm$ $15^{17}$; and an American study achieved scores of 76.6 $\pm 20.6,77.7 \pm 20.6$, and $75.2 \pm 22.6$, respectively. ${ }^{18}$ Nonetheless the Canadian centres were able to achieve a significantly better result in most items and in the summary scores. This might be explained by cross-cultural (different expectations from families), as well as administrative differences (nurse-patient and doctor-patient ratios), but it may also indicate room for further improvement.

Independent factors that affected satisfaction with overall care and identified by this study can be grouped into: care of the patient and family (concern and caring for the patient and family; agitation management), professional care (frequency of communication by nurses; physician skill and competence), and the ICU environment (atmosphere of the ICU and its waiting room). Consistent with prior studies, none of the patient's or respondent's characteristics, including the ICU survival status, was found to be independently associated with satisfaction of overall care. ${ }^{16,19}$ Setting professional skills aside, the perceived physician competence and amount of concern and care shown to patients and their families were largely affected by the communication skill of the health care providers and their manner when interacting with patients and families. The importance of communication has been emphasised by numerous studies. ${ }^{20-25}$ One study found that longer periods of communication between health care providers and 
TABLE 2. Family satisfaction with overall care and role in decision-making, and benchmarking with Canadian multicentre database

\begin{tabular}{|c|c|c|c|c|c|c|c|c|c|c|}
\hline & \multicolumn{7}{|c|}{ PYNICU, Hong Kong (present study) } & \multicolumn{2}{|c|}{$\begin{array}{l}\text { Canadian multicentre } \\
\text { database (CARENET) } \dagger\end{array}$} & \multirow[t]{3}{*}{$P$ valuef } \\
\hline & \multirow[t]{2}{*}{ No. } & \multicolumn{5}{|c|}{ Responses (\%)* } & \multirow{2}{*}{$\begin{array}{c}\text { Score } \\
\text { (mean } \pm \text { SD) }\end{array}$} & \multirow[t]{2}{*}{ No. } & \multirow{2}{*}{$\begin{array}{c}\text { Score } \\
\text { (mean } \pm \text { SD) }\end{array}$} & \\
\hline & & Excellent & $\begin{array}{l}\text { Very } \\
\text { good }\end{array}$ & Good & Fair & Poor & & & & \\
\hline \multicolumn{11}{|l|}{ Aspect of care: care of patient } \\
\hline Concern and caring for patients & 721 & 55.5 & 34.4 & 9 & 1.1 & 0 & $86.1 \pm 17.6$ & 2468 & $91.9 \pm 15.4$ & $<0.001$ \\
\hline Pain management & 676 & 36.7 & 44.5 & 15.8 & 2.5 & 0.4 & $78.6 \pm 20.1$ & 2382 & $89.0 \pm 17.3$ & $<0.001$ \\
\hline Breathlessness management & 590 & 38.5 & 40.8 & 16.8 & 3.6 & 0.3 & $78.4 \pm 21.0$ & 2286 & $89.2 \pm 18.0$ & $<0.001$ \\
\hline Agitation management & 578 & 33 & 39.3 & 21.3 & 6.2 & 0.2 & $74.7 \pm 22.5$ & 2244 & $84.8 \pm 21.2$ & $<0.001$ \\
\hline \multicolumn{11}{|l|}{ Care of family } \\
\hline Consideration of family needs & 718 & 49.2 & 34.5 & 13.9 & 2.4 & 0 & $82.6 \pm 19.9$ & 2440 & $85.1 \pm 21.5$ & $<0.001$ \\
\hline Emotional support for family & 660 & 37.1 & 41.4 & 17.3 & 4.1 & 0.2 & $77.8 \pm 21.1$ & 2394 & $81.5 \pm 23.2$ & $<0.001$ \\
\hline Spiritual support for family & 412 & 30.8 & 33 & 21.8 & 14.3 & 0 & $70.1 \pm 25.8$ & 1584 & $78.8 \pm 25.1$ & $<0.001$ \\
\hline Coordination of care & 710 & 44.5 & 36.9 & 16.1 & 2.5 & 0 & $80.8 \pm 20.2$ & 2444 & $87.8 \pm 18.5$ & $<0.001$ \\
\hline Concern and caring for family & 720 & 50 & 35.7 & 12.1 & 1.9 & 0.3 & $83.3 \pm 19.6$ & 2450 & $86.4 \pm 20.5$ & $<0.001$ \\
\hline \multicolumn{11}{|l|}{ Professional care } \\
\hline Nursing skill and competence & 724 & 45.6 & 39.2 & 13.5 & 1.7 & 0 & $82.2 \pm 19.0$ & 2454 & $92.3 \pm 14.7$ & $<0.001$ \\
\hline Frequency of communication by nurses & 729 & 45.8 & 37 & 14.1 & 2.7 & 0.3 & $81.3 \pm 20.5$ & 2448 & $85.4 \pm 21.6$ & $<0.001$ \\
\hline Physician skill and competence & 714 & 43.8 & 38.1 & 15 & 2.8 & 0.3 & $80.6 \pm 20.6$ & 2432 & $88.1 \pm 19.2$ & $<0.001$ \\
\hline Frequency of communication by physicians & 704 & 31.3 & 37.4 & 21.7 & 8.9 & 0.7 & $72.4 \pm 24.3$ & 2408 & $70.6 \pm 29.7$ & 0.887 \\
\hline Support from social workers & 345 & 28.1 & 36.8 & 24.3 & 9 & 1.7 & $70.1 \pm 25.1$ & 1336 & $74.3 \pm 29.6$ & $<0.001$ \\
\hline Support from pastors & 228 & 26.8 & 32 & 28.9 & 11.8 & 0.4 & $68.2 \pm 25.0$ & 1238 & $77.8 \pm 25.8$ & $<0.001$ \\
\hline \multicolumn{11}{|l|}{ ICU environment } \\
\hline Atmosphere of ICU & 717 & 23.8 & 40 & 25.4 & 10.6 & 0.1 & $69.2 \pm 23.4$ & 2436 & $80.1 \pm 22.7$ & $<0.001$ \\
\hline Atmosphere of ICU waiting room & 663 & 21.9 & 39.7 & 27 & 11 & 0.5 & $67.9 \pm 23.6$ & 2370 & $64.9 \pm 29.3$ & 0.201 \\
\hline Overall satisfaction with care & 729 & 45 & 39.9 & 13.6 & 1.5 & 0 & $82.1 \pm 18.8$ & 2466 & $85.0 \pm 20.5$ & $<0.001$ \\
\hline \multicolumn{11}{|l|}{ Aspect of decision-making } \\
\hline Ease of getting information & 716 & 38.5 & 42.6 & 15.4 & 3.2 & 0.3 & $79.0 \pm 20.4$ & 2436 & $85.5 \pm 20.5$ & $<0.001$ \\
\hline Understanding information & 715 & 33.4 & 44.2 & 19.2 & 2.9 & 0.3 & $76.9 \pm 20.4$ & 2440 & $83.6 \pm 20.2$ & $<0.001$ \\
\hline Honesty of information & 712 & 36.1 & 43.1 & 17.3 & 3.4 & 0.1 & $77.9 \pm 20.4$ & 2438 & $84.4 \pm 21.6$ & $<0.001$ \\
\hline Completeness of information & 680 & 37.2 & 40.3 & 18.1 & 4.0 & 0.4 & $77.5 \pm 21.5$ & 2442 & $82.8 \pm 23.2$ & $<0.001$ \\
\hline Consistency of information & 696 & 32.0 & 45.0 & 19.1 & 3.9 & 0 & $76.3 \pm 20.4$ & 2396 & $78.3 \pm 25.6$ & $<0.001$ \\
\hline Inclusion in decision-making & 695 & 30.5 & 36.5 & 29.5 & 1.9 & 1.6 & $73.1 \pm 22.6$ & 2402 & $75.4 \pm 30.3$ & $<0.001$ \\
\hline Involved at the right time in decision-making & 638 & 86.7 & - & 12.7 & - & 0.6 & $93.0 \pm 18.2$ & 2204 & $92.7 \pm 21.8$ & 0.266 \\
\hline Received appropriate amount of information & 641 & 90.3 & - & - & - & 9.7 & $90.3 \pm 29.6$ & 2246 & $89.3 \pm 30.9$ & 0.460 \\
\hline $\begin{array}{l}\text { Had enough time to think in decision-making } \\
\text { process }\end{array}$ & 668 & 85.9 & - & - & - & 14.1 & $85.9 \pm 34.8$ & 2184 & $89.8 \pm 30.2$ & 0.005 \\
\hline Supported during decision-making & 638 & 23.0 & 24.3 & 46.9 & 5.3 & 0.5 & $66.0 \pm 22.7$ & 2246 & $72.1 \pm 25.8$ & $<0.001$ \\
\hline Control over care & 685 & 37.2 & 37.7 & 15.5 & 5.8 & 3.8 & $74.7 \pm 26.3$ & 2336 & $68.3 \pm 28.8$ & $<0.001$ \\
\hline Given right amount of hope & 693 & 81.1 & - & 11.1 & - & 7.8 & $86.7 \pm 29.7$ & 2316 & $87.8 \pm 27.8$ & 0.582 \\
\hline $\begin{array}{l}\text { Agreement within family regarding care } \\
\text { patient received }\end{array}$ & 702 & 9.3 & 74.8 & 13.2 & 2.6 & 0.1 & $72.6 \pm 14.4$ & 2330 & $79.8 \pm 22.6$ & $<0.001$ \\
\hline $\begin{array}{l}\text { Adequate time to address concerns and } \\
\text { answer questions }\end{array}$ & 644 & 80.7 & - & - & - & 19.3 & $80.7 \pm 39.5$ & 2212 & $90.2 \pm 29.7$ & $<0.001$ \\
\hline Satisfaction with amount of health care & 704 & 23.2 & 46.6 & 29.4 & 0.6 & 0.3 & $72.9 \pm 18.8$ & 2420 & $83.5 \pm 22.7$ & $<0.001$ \\
\hline $\begin{array}{l}\text { Overall satisfaction with role in decision- } \\
\text { making }\end{array}$ & 694 & 17.9 & 56.5 & 24.9 & 0.3 & 0.4 & $72.8 \pm 17.2$ & 2308 & $76.3 \pm 25.6$ & $<0.001$ \\
\hline
\end{tabular}

Abbreviations: CARENET = the Canadian Researchers at the End of Life Network; ICU = intensive care unit; PYNICU = Department of Intensive Care,

Pamela Youde Nethersole Eastern Hospital; SD = standard deviation

* Because of rounding, not all percentages total 100

† Written communication, Daren Heyland, Feb 2014

‡ $\mathrm{P}$ value when each item score of PYNICU and CARENET was compared using Mann-Whitney $U$ test 
TABLE 3. Factors independently associated with complete satisfaction

\begin{tabular}{|c|c|c|}
\hline & Odds ratio (95\% confidence interval) & $P$ value \\
\hline \multicolumn{3}{|l|}{ Aspect of care $(n=445)^{\star}$} \\
\hline Concern and caring for patients & $2.35(1.06-5.19)$ & 0.035 \\
\hline Agitation management & $4.15(2.00-8.61)$ & $<0.001$ \\
\hline Concern and caring for family & $2.76(1.29-5.90)$ & 0.009 \\
\hline Frequency of communication by nurses & $2.60(1.31-5.15)$ & 0.006 \\
\hline Physician skill and competence & $3.44(1.75-6.76)$ & $<0.001$ \\
\hline Atmosphere of ICU & $4.77(1.54-14.78)$ & 0.007 \\
\hline Atmosphere of ICU waiting room & $5.86(1.70-20.19)$ & 0.005 \\
\hline \multicolumn{3}{|l|}{ Aspect of decision-making $(n=524) \dagger$} \\
\hline Honesty of information & $4.29(1.81-10.21)$ & 0.001 \\
\hline Completeness of information & $2.75(1.16-6.55)$ & 0.022 \\
\hline Control over care & $2.32(1.28-4.22)$ & 0.006 \\
\hline Agreement within family regarding care patient received & $3.34(1.51-7.38)$ & 0.003 \\
\hline Satisfaction with amount of health care & $6.56(3.54-12.15)$ & $<0.001$ \\
\hline Age of respondent $\geq 47$ years & $2.70(1.47-4.93)$ & 0.001 \\
\hline
\end{tabular}

Abbreviation: ICU = intensive care unit

* All part I items except for "spiritual support for family", "support from social workers", and "support from pastors" were included in the analysis

† Age and sex of respondents, and all part 2 items except for "given right amount of hope" were included in the analysis

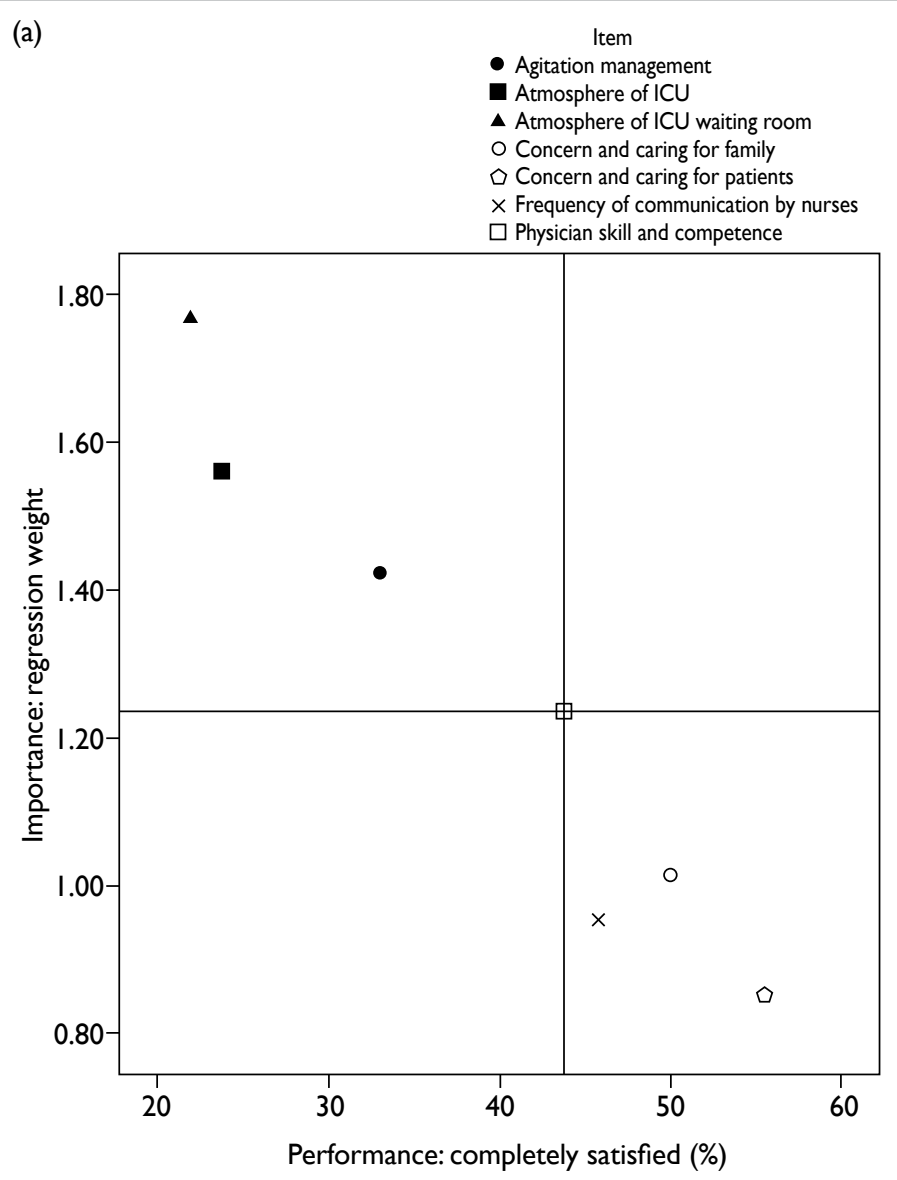

(b)

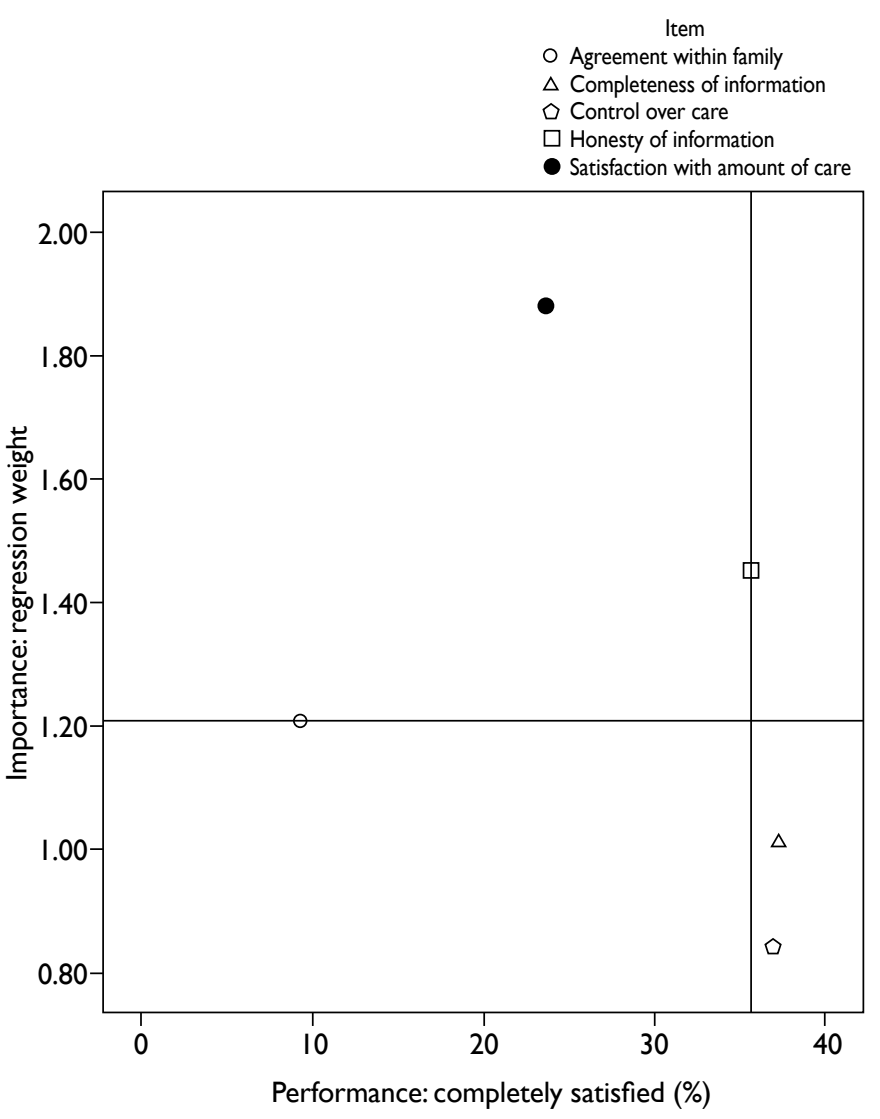

FIG I. Performance-importance plots of satisfaction with (a) overall care and (b) role in decision-making

(a) Horizontal and vertical lines indicate the medians of regression weights (1.236) and performances (43.8), respectively

(b) Horizontal and vertical lines indicate the medians of regression weights (I.207) and performances (35.7), respectively

Abbreviation: ICU = intensive care unit 

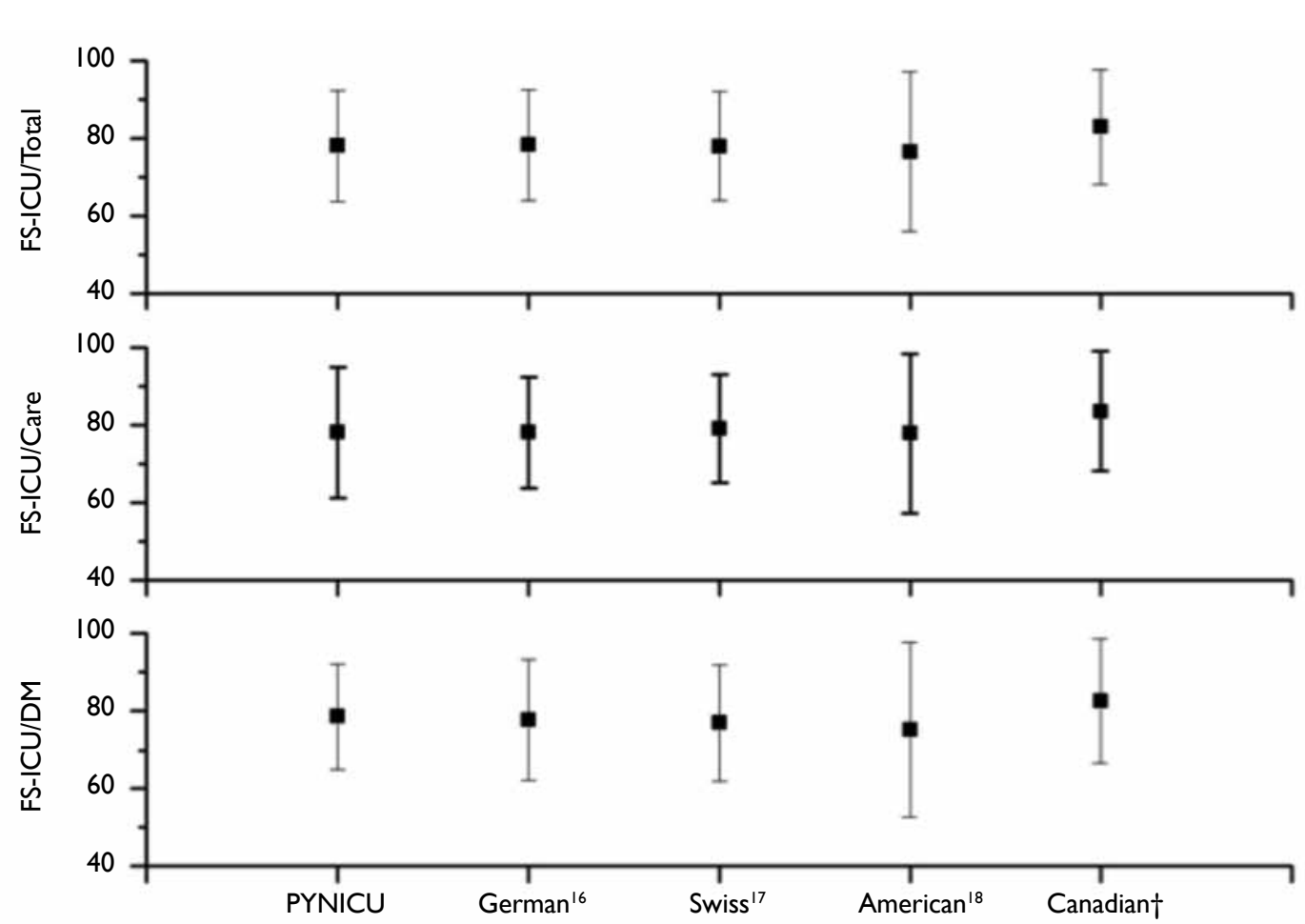

FIG 2. Comparison of mean total and subscores across centres*16-18

Abbreviations: FS-ICU = Family Satisfaction in the Intensive Care Unit questionnaire; PYNICU = Department of Intensive Care,

Pamela Youde Nethersole Eastern Hospital

* Subscores for satisfaction with overall ICU care (FS-ICU/Care) and role in decision-making (FS-ICU/DM), and a total score (FS-

ICU/Total) are shown, with error bars denoting standard deviations

† From a multicentre Canadian database (written communication, Daren Heyland, Feb 20।4)

families was associated with reduced anxiety among family members of ICU patients. ${ }^{24}$ They reported a median (range) time of staff contact as 10 (1-60) minutes. In addition to the duration, a proactive, structured, and multidisciplinary communication strategy that incorporated the five objectives in the mnemonic "VALUE" (to Value and appreciate what the family members said, to Acknowledge the family members' emotions, to Listen, to ask openended questions that would allow the caregiver to Understand who the patient was as a person, and to Elicit questions from family members) was shown to lessen symptoms of anxiety, depression, and posttraumatic stress disorder. ${ }^{25}$ Education and training in communication skills, especially the power of listening and to allow families more opportunity to speak during conferences also improved family satisfaction in the ICU. ${ }^{26}$ It is also essential to diagnose the root cause of any communication problem. ${ }^{15}$ Removing barriers in the health care system that discourage communication, for example heavy workload rendering insufficient time spent with families and restrictive visiting policies, would be beneficial. ${ }^{27}$
Factors in the left upper quadrant of the performance-importance plots (Fig 1) had greater regression weights but performed less satisfactorily, and therefore warrant more urgent attention. Among these were the ICU and waiting room environment. The questionnaire items do not specify the particular areas of concern that individual families had in mind, but responses to the three open-ended questions were illuminating. Comments related to the ICU environment focused on the availability of facilities for patients (visual and audio entertainment devices) and their families (chairs and toilet), ICU noise level, room temperature, space, and privacy. In fact, the ICU environment has been repeatedly identified as a factor that affects satisfaction. ${ }^{13,18,19}$ One study found that migration of an ICU with multiple beds in one ward to another with single-room design significantly improved family and patient satisfaction. ${ }^{13}$ These findings offer opportunities for improvement, and also provide valuable information for administrators when designing a new ICU.

Agitation management also warranted more urgent attention (Fig 1a). Although evidence supports maintenance of a light rather than deep 
level of sedation in adult critically ill patients to shorten duration of mechanical ventilation and ICU length of stay, ${ }^{28,29}$ a balance needs to be struck to prevent excessive pain, agitation, or adverse experiences that are associated with a higher incidence of post-traumatic stress disorder in ICU survivors and could negatively impact their families. $^{30}$ The revised 2013 version of Clinical Practice Guidelines for the Management of Pain, Agitation, and Delirium in Adult ICU Patients has recommended routine monitoring of the depth of sedation and targeted titration of preferably nonbenzodiazepine sedatives. ${ }^{31}$

Our subscore for decision-making was higher than that for overall care, in contrast to the overseas counterparts. ${ }^{16-18}$ We do not know if this is unique to the Chinese population since no other Chinese survey is available for comparison. One interesting finding was that younger respondents were less satisfied with their role in decision-making than older respondents. A similar observation has been made before. ${ }^{32}$ In this information explosion era where electronic data are easily available, it can be understood that the younger generation wants to play a greater role in making decisions for their sick family member. A paternalistic approach will be less appealing to our future generation, and a deliberative model should therefore be adopted, with an emphasis on provision of complete and honest information to increase their sense of control over the care of their family member.

There are limitations to our study. First, the reason for refusal to participate in the survey was not documented and therefore we cannot rule out a response bias, where dissatisfied families might have declined participation in the survey, thus overestimating satisfaction. The high return rate compared with other studies (76.6\% vs $27.8-75.4 \%{ }^{15-17}$ ) would have lessened any effect of a response bias. Second, social desirability bias cannot be ruled out as most respondents completed the questionnaire while their sick family member was still under our care. We tried to minimise this by reassuring families of the confidentiality of their response and providing an envelope in which to return the completed questionnaire that was only opened by researchers at a later time. Third, questionnaires completed before ICU discharge might not reflect the whole ICU experience. Recruiting NOKs when the patient was nearing ICU discharge reduced premature data capture and prevented the otherwise increased administrative cost, increased recall bias, and anticipated lower response rate that would be involved when tracing eligible NOKs following ICU discharge. Fourth, FS-ICU has not been validated in the Chinese language. The Chinese (Taiwan) version provided by CARENET was modified by the co-authors wherein Taiwanese terms were replaced by ones familiar to the Hong Kong people and questions on the respondent's demographics were added as in the original English questionnaire. This modified version was circulated to and approved by all co-authors to ensure face validity. The high return rate of the questionnaire and the high response rate to questions $(95.0 \%)$ indicated feasibility of this modified Chinese version. ${ }^{11}$ Last, this was a singlecentre study and thus generalisability of the results to other settings may not be appropriate.

\section{Conclusions}

Family satisfaction is an important measure of ICU quality. We found that families were satisfied with the ICU care we provided and with their role in decision-making. Their satisfaction was comparable with most overseas centres. Nonetheless there remains room for improvement when compared with the Canadian database. Future initiatives will focus on improving the ICU environment, agitation management, and enhancing communication with families.

\section{Acknowledgements}

We wish to thank all members of the FAME team including Dr Arthur CW Lau, Ms Nora LP Kwok, Ms L Lau, Ms CH Lee, and Ms HY Wong for their administrative advice and contribution in data collection and entry, and Ms CH Li, Ms WY So, and Ms PS Chiu for subject recruitment. We also wish to thank the Canadian Researchers at the End of Life Network for sharing their FS-ICU database. Current versions of the FS-ICU questionnaire can be found on their website <www.thecarenet.ca/57-researchers/ our-projects/family-satisfaction-survey>.

\section{References}

1. Davidson JE, Powers K, Hedayat KM, et al. Clinical practice guidelines for support of the family in the patientcentered intensive care unit: American College of Critical Care Medicine Task Force 2004-2005. Crit Care Med 2007;35:605-22.

2. Lewin SA, Skea ZC, Entwistle V, Zwarenstein M, Dick J. Interventions for providers to promote a patient-centred approach in clinical consultations. Cochrane Database Syst Rev 2001;(4):CD003267.

3. Roter DL, Hall JA, Kern DE, Barker LR, Cole KA, Roca RP. Improving physicians' interviewing skills and reducing patients' emotional distress. A randomized clinical trial. Arch Intern Med 1995;155:1877-84.

4. Stewart M, Brown JB, Donner A, et al. The impact of patient-centered care on outcomes. J Fam Pract 2000;49:796-804.

5. Heyland DK, Tranmer JE; Kingston General Hospital ICU Research Working Group. Measuring family satisfaction with care in the intensive care unit: the development of a questionnaire and preliminary results. J Crit Care 2001;16:142-9. 
6. Sundararajan K, Martin M, Rajagopala S, Chapman MJ. Posttraumatic stress disorder in close relatives of intensive care unit patients' evaluation (PRICE) study. Aust Crit Care 2014;27:183-7.

7. Schmidt M, Azoulay E. Having a loved one in the ICU: the forgotten family. Curr Opin Crit Care 2012;18:540-7.

8. Davidson JE, Jones C, Bienvenu J. Family response to critical illness: postintensive care syndrome-family. Crit Care Med 2012;40:618-24.

9. Flaatten $\mathrm{H}$. The present use of quality indicators in the intensive care unit. Acta Anaesthesiol Scand 2012;56:107883.

10. de Vos M, Graafmans W, Keesman E, Westert G, van der Voort PH. Quality measurement at intensive care units: which indicators should we use? J Crit Care 2007;22:26774 .

11. Stricker KH, Niemann S, Bugnon S, Wurz J, Rohrer O, Rothen HU. Family satisfaction in the intensive care unit: cross-cultural adaptation of a questionnaire. J Crit Care 2007;22:204-11.

12. Wall RJ, Engelberg RA, Downey L, Heyland DK, Curtis JR. Refinement, scoring, and validation of the family satisfaction in the intensive care unit (FS-ICU) survey. Crit Care Med 2007;35:271-9.

13. Jongerden IP, Slooter AJ, Peelen LM, et al. Effect of intensive care environment on family and patient satisfaction: a before-after study. Intensive Care Med 2013;39:1626-34.

14. Tastan S, Iyigun E, Ayhan H, Kilickaya O, Yilmaz AA, Kurt E. Validity and reliability of Turkish version of family satisfaction in the intensive care unit. Int J Nurs Pract 2014;20:320-6.

15. Heyland DK, Rocker GM, Dodek PM, et al. Family satisfaction with care in the intensive care unit: results of a multiple center study. Crit Care Med 2002;30:1413-8.

16. Schwarzkopf D, Behrend S, Skupin H, et al. Family satisfaction in the intensive care unit: a quantitative and qualitative analysis. Intensive Care Med 2013;39:1071-9.

17. Stricker KH, Kimberger O, Schmidlin K, Zwahlen M, Mohr U, Rothen HU. Family satisfaction in the intensive care unit: what makes the difference? Intensive Care Med 2009;35:2051-9.

18. Osborn TR, Curtis JR, Nielsen EL, Back AL, Shannon $\mathrm{SE}$, Engelberg RA. Identifying elements of ICU care that families report as important but unsatisfactory: decision-making, control, and ICU atmosphere. Chest 2012;142:1185-92.

19. Hunziker S, McHugh W, Sarnoff-Lee B, et al. Predictors and correlates of dissatisfaction with intensive care. Crit Care Med 2012;40:1554-61.

20. Scheunemann LP, McDevitt M, Carson SS, Hanson LC. Randomized, controlled trials of interventions to improve communication in intensive care: a systematic review.
Chest 2011;139:543-54.

21. Kodali S, Stametz RA, Bengier AC, Clarke DN, Layon AJ, Darer JD. Family experience with intensive care unit care: association of self-reported family conferences and family satisfaction. J Crit Care 2014;29:641-4.

22. Lily CM, De Meo DL, Sonnar LA, et al. An intensive communication intervention for the critically ill. Am J Med 2000;109:469-75.

23. Shelton W, Moore CD, Socaris S, Gao J, Dowling J. The effect of a family support intervention on family satisfaction, length-of-stay, and cost of care in the intensive care unit. Crit Care Med 2010;38:1315-20.

24. Rusinova K, Kukal J, Simek J, Cerny V; DEPRESS study working group. Limited family members/staff communication in intensive care units in the Czech and Slovak Republics considerably increases anxiety in patients' relatives-the DEPRESS study. BMC Psychiatry 2014;14:21.

25. Lautrette A, Darmon M, Megarbane B, et al. A communication strategy and brochure for relatives of patients dying in the ICU. N Engl J Med 2007;356:469-78.

26. McDonagh JR, Elliott TB, Engelberg RA, et al. Family satisfaction with family conferences about end-of-life care in the intensive care unit: increased proportion of family speech is associated with increased satisfaction. Crit Care Med 2004;32:1484-8.

27. Curtis JR, Patrick DL, Shannon SE, Treece PD, Engelberg RA, Rubenfeld GD. The family conference as a focus to improve communication about end-of-life care in the intensive care unit: opportunities for improvement. Crit Care Med 2001;29(2 Suppl):N26-33.

28. Kress JP, Pohlman AS, O'Connor MF, Hall JB. Daily interruption of sedative infusions in critically ill patients undergoing mechanical ventilation. $\mathrm{N}$ Engl $\mathrm{J}$ Med 2000;342:1471-7.

29. Girard TD, Kress JP, Fuchs BD, et al. Efficacy and safety of a paired sedation and ventilator weaning protocol for mechanically ventilated patients in intensive care (Awakening and Breathing Controlled trial): a randomised controlled trial. Lancet 2008;371:126-34.

30. Granja C, Gomes E, Amaro A, et al. Understanding posttraumatic stress disorder-related symptoms after critical care: the early illness amnesia hypothesis. Crit Care Med 2008;36:2801-9.

31. Barr J, Fraser GL, Puntillo K, et al. Clinical practice guidelines for the management of pain, agitation, and delirium in adult patients in the intensive care unit. Crit Care Med 2013;41:263-306.

32. Crow R, Gage H, Hampson S, et al. The measurement of satisfaction with healthcare: implications for practice from a systematic review of the literature. Health Technol Assess 2002;6:1-244. 